\title{
Symposium review: Amino acid uptake by the mammary glands: Where does the control lie? ${ }^{1}$
}

\author{
John P. Cant, ${ }^{* 2}$ Julie J. M. Kim, ${ }^{*}$ Scott R. L. Cieslar, ${ }^{*}$ and John Doelman† \\ *Department of Animal Biosciences, University of Guelph, Ontario, N1G 2W1 Canada \\ †Nutreco Nederland BV, 5831, JN, Boxmeer, the Netherlands
}

\begin{abstract}
Milk protein yield responses to changes in the profile of essential amino acids absorbed by the gastrointestinal tract or circulating in blood plasma do not follow the classic limiting amino acid response, in part because of an ability of the mammary glands to modify their blood flow rate and net clearance of amino acids out of plasma. The hypothesis that mammary blood flow is locally regulated to maintain ATP balance accounts for observed changes in flow due to postruminal glucose, insulin, and essential amino acid (EAA) infusions. An additional hypothesis that net mammary uptakes of metabolites from blood are affected by perturbations in their respective arterial concentrations and the rate of mammary blood flow also appears to hold for the energy metabolites glucose, acetate, $\beta$-hydroxybutyrate, and fatty acids. However, net EAA uptakes by the mammary glands are poorly predicted by models considering arterial concentrations and blood flow rates only. Evidence points to intramammary protein synthesis and secretion as the determinant of net EAA uptake. The intracellular signaling network anchored by the mechanistic target of rapamycin complex 1 stands as an excellent candidate to explain nutritional effects on milk protein synthesis because it integrates information on physiological and nutritional state to affect protein synthesis and cell metabolism, growth, proliferation, and differentiation in many cell types. In mammary cells in vitro and in vivo, the mechanistic target of rapamycin complex 1, integrated stress response, and glycogen synthase kinase-3 networks that contribute to regulation of initiation of mRNA translation are responsive to acute changes in nutrient supply and EAA profile. However, after several days of postruminal infusion of balanced and imbalanced EAA profiles, these signaling networks
\end{abstract}

Received September 15, 2017.

Accepted January 28, 2018.

${ }^{1}$ Presented as part of the ADSA Lactation Symposium: The New and Old of Mammary Gland Physiology and Milk Synthesis at the ADSA Annual Meeting, Pittsburgh, Pennsylvania, June 2017.

${ }^{2}$ Corresponding author: jcant@uoguelph.ca do not appear to continue to account for changes in milk protein yields. Gene expression evidence suggests that regulation of components of the unfolded protein response that control biogenesis of the endoplasmic reticulum and differentiation of a secretory phenotype may contribute to effects of nutrition on milk protein yield. Connections between early signaling events and their long-term consequences should be sought.

Key words: mammary gland, amino acid, milk synthesis

\section{INTRODUCTION}

The formulation and evaluation of diets fed to dairy cows is based on mathematical models that describe the flow of nutrients through the processes of digestion and absorption. Metabolizable protein and EAA supplies are typically predicted by estimating microbial, undegraded dietary and endogenous protein outflows from the reticulorumen (NRC, 2001; Sauvant and Nozière, 2016). A variable proportion of the absorbed EAA is captured in milk protein, depending on characteristics of the diet such as energy and MP content, level of intake, stage of lactation of the cow, health status, and so on. This variability in EAA capture can be accounted for in nutrient flow models if the underlying mechanisms of control are sufficiently understood. Progress in explaining variation in capture of metabolizable EAA in milk protein has been greatly facilitated by application of the arteriovenous difference technique by which net EAA uptakes by the mammary glands can be measured (Linzell, 1974). An estimate of mammary blood flow (MBF) rate is required to obtain uptake values from arteriovenous concentration differences, and through such measurements, nutritional effects on MBF have been recorded. Net uptake is a consequence of bidirectional transport across the plasma membranes of mammary epithelial cells. Net uptake values can be used to estimate rates of AA interconversion and catabolism and relations to other intra- and extra-mammary pathways of milk synthesis and nutrient metabolism. This review will attempt to disentangle relationships 
between MBF, transmembrane transport, and net uptake, and focus on the main factor that regulates mammary EAA uptake, which is the control of milk protein synthesis. A framework for exploring variation in milk protein yield will be presented.

\section{MAMMARY AA UPTAKE IS REGULATED BY CONTROL OF MILK PROTEIN SYNTHESIS}

Net mammary AA uptake represents loss into milk, mostly as protein, tissue protein accretion, and catabolism. Milk protein yield accounts for approximately $90 \%$ of net mammary AA uptake (Cant et al., 1993). Milk protein yield of cows is stimulated by an increased MP supply (Daniel et al., 2016), apparently because of higher concentrations of EAA in blood and faster delivery of these EAA to the mammary glands. Attempts to identify which EAA is most limiting for milk protein yield have shown that milk protein yield is not limited by supply of a single EAA. Evidence against the limiting EAA phenomenon includes stimulation of milk protein yield by mutually exclusive sets of EAA in cows (Schwab et al., 1976) and mice (Liu et al., 2017), equal losses in milk protein yield when Met, Lys, His, Phe, or Leu are subtracted from the duodenal EAA supply (Weekes et al., 2006; Doelman et al., 2015a,b), and stimulation of milk protein yield by insulin or glucose when EAA concentrations in blood decrease (Mackle et al., 2000; Toerien et al., 2010).

Mammary cells that synthesize milk protein are exposed to EAA concentrations that are a function of their concentrations in arterial blood and the rate of MBF. Reasons why milk protein yield does not respond according to a limiting AA phenomenon may include the effect of extra-mammary organs on arterial EAA concentrations and local regulation of MBF. For example, when graded levels of Met from 0 to $32 \mathrm{~g} / \mathrm{d}$ were infused into the duodenum of lactating cows, MBF decreased in a quadratic fashion and net mammary uptake of Met was not affected (Guinard and Rulquin, 1995). When His was added to an abomasal infusate of EAA lacking His, MBF in goats decreased and net mammary uptake of His was not affected (Bequette et al., 2000). Increasing Lys concentration in an otherwise complete mix of AA + glucose infused into the jugular veins of fasted goats also caused MBF to decrease (Guo et al., 2017). Guo et al. (2017) reported a linear decrease in concentrations of $\mathrm{NO}_{3}{ }^{-}+\mathrm{NO}_{2}{ }^{-}$in samples of the mammary venous outflow as Lys was added to infusates, indicating lower output of the short-lived vasodilator NO. Synthesis of NO and other vasodilators in the mammary glands may be regulated by AA supply, but a potential mechanism has received very little study. Vascular NO is produced by endothelial NO synthase from oxidation of a guanidino $\mathrm{N}$ of Arg. The synthase is regulated by phosphorylation, acylation, and calmodulin binding in response to numerous chemical and mechanical stimuli acting upon the endothelium (Dudzinski et al., 2006). Whether and how physiological concentrations of the Arg substrate influence rates of endothelial NO synthesis is a matter of some debate. The $\mathrm{K}_{\mathrm{m}}$ of endothelial NO synthase for Arg is 50 times lower than normal intracellular Arg concentration (Cardounel et al., 2007), so reaction velocity would not be expected to respond to increased Arg supply. However, adding 2\% Arg to the drinking water of rabbits partially restored aortic endothelial NO synthesis and the vasodilatory response to acetylcholine that had been impaired by cholesterol feeding (Böger et al., 1997). Supplementary Arg for lactating sows did not affect MBF (Krogh et al., 2017) but subtraction of Arg from a mixture of EAA infused abomasally into cows tended to decrease MBF (Doepel and Lapierre, 2011). The subtraction of Arg did not affect milk protein yield (Doepel and Lapierre, 2011). An Arg-induced elevation in blood flow, when it occurs, may be due to competition between Arg and endogenous methylarginine inhibitors that can accumulate (Böger et al., 1997; Cardounel et al., 2007).

It is tempting to speculate that the mammary vasculature is endowed with a mechanism to respond to individual EAA supplies. However, the involvement of a canonical energy-sensing vasoactive pathway has not yet been ruled out. Much as has been described for cardiac and skeletal muscle (Deussen et al., 2012; Hellsten et al., 2012), the mammary glands release end products of oxidative metabolism and ATP synthesis into the interstitium, which activate endothelial synthesis of NO and another vasodilator, prostacyclin (Cieslar et al., 2014). This set of mechanisms (Figure 1) allows MBF to increase or decrease according to the rate of milk synthesis. Mammary uptake and catabolism of the energy metabolites glucose, acetate, and BHB is dependent to some degree on their respective arterial concentrations (Cant et al., 2016), so the vasodilatory mechanisms also cause MBF to decrease when concentrations of energy metabolites rise (Cant et al., 1993, 2002; Cieslar et al., 2014). Computer simulation of intracellular ATP turnover and its effect on capillary geometry, and ensuing changes in rates of blood flow and net metabolite uptake (Cant et al., 2003), indicates that elevated concentrations of acetate and BHB in circulation during single EAA infusions (Guinard and Rulquin, 1995; Weekes et al., 2006) may be responsible for the decreased MBF rates that have been observed. Whether the drop in mammary NO release and MBF observed by Guo et al. (2017) as i.v. Lys supply increased was caused by an 
imbalance in mammary supply of energy metabolites or AA, possibly Arg, remains to be determined.

Hypotheses to explain what causes the increases in acetate and BHB concentrations during EAA infusion have not been tested but may involve a decreased efficiency of utilization by adipose tissue for lipogenesis. During glucose or insulin infusion, which is stimulatory to adipose lipogenesis, arterial acetate, BHB, and nonesterified fatty acid concentrations decline (Eisemann and Huntington, 1994; Rigout et al., 2002) and MBF increases (Mackle et al., 2000; Rulquin et al., 2004). The insulin-induced mammary hyperemia can be quantitatively accounted for by the drop in energy metabolite concentrations (Cant et al., 2003). In addition to stimulating MBF, euglycemic insulin infusion into lactating cows and goats also causes an increase in milk protein yield (Mackle et al., 2000; Bequette et al., 2001), which supports the notion that blood flow affects milk protein yield. However, insulin also causes a decrease in EAA concentrations in arterial plasma, to the extent that the rate of delivery of EAA to the mammary glands, despite the hyperemia, is actually impaired by insulin (Mackle et al., 2000; Bequette et al., 2001). Insulin appears to directly stimulate milk protein synthesis, which retains more of the arterial EAA influx and causes a smaller proportion to undergo catabolism in the mammary glands or exit via the venous drainage (Mackle et al., 2000; Bequette et al.,
2001). More EAA is transported into the mammary epithelial cell than is used and the excess returns to the venous drainage (Bequette et al., 2000). The insulin response is a definitive reminder that net EAA uptake by the mammary glands is determined by the rates of milk protein synthesis, tissue protein accretion, and EAA catabolism, and if increased EAA delivery to the mammary glands, such as occurs when MP supply goes up, is going to affect net EAA uptake, it has to affect one or more of those pathways first. Approximately $90 \%$ of net mammary AA uptake is accounted for by milk protein secretion, which means that control of milk protein yield is the primary factor that regulates net mammary AA uptake.

Measurements of net mammary AA uptake by arteriovenous difference methodology are often interpreted as measurements of AA transport rate, which is erroneous because of the bidirectional fluxes of AA across the plasma membrane (Bequette et al., 2000; Shennan and Boyd, 2014). Net uptake should be interpreted as sequestration and irreversible loss of AA. Does this mean that AA transport exerts no control over net AA utilization? Determining sensitivity of milk protein output to changes in AA transporter activities according to the methods of metabolic control analysis (Wright et al., 2008) would shed light on this question, but such an endeavor has not been attempted yet, to our knowledge. Several members of the SLC families of genes coding

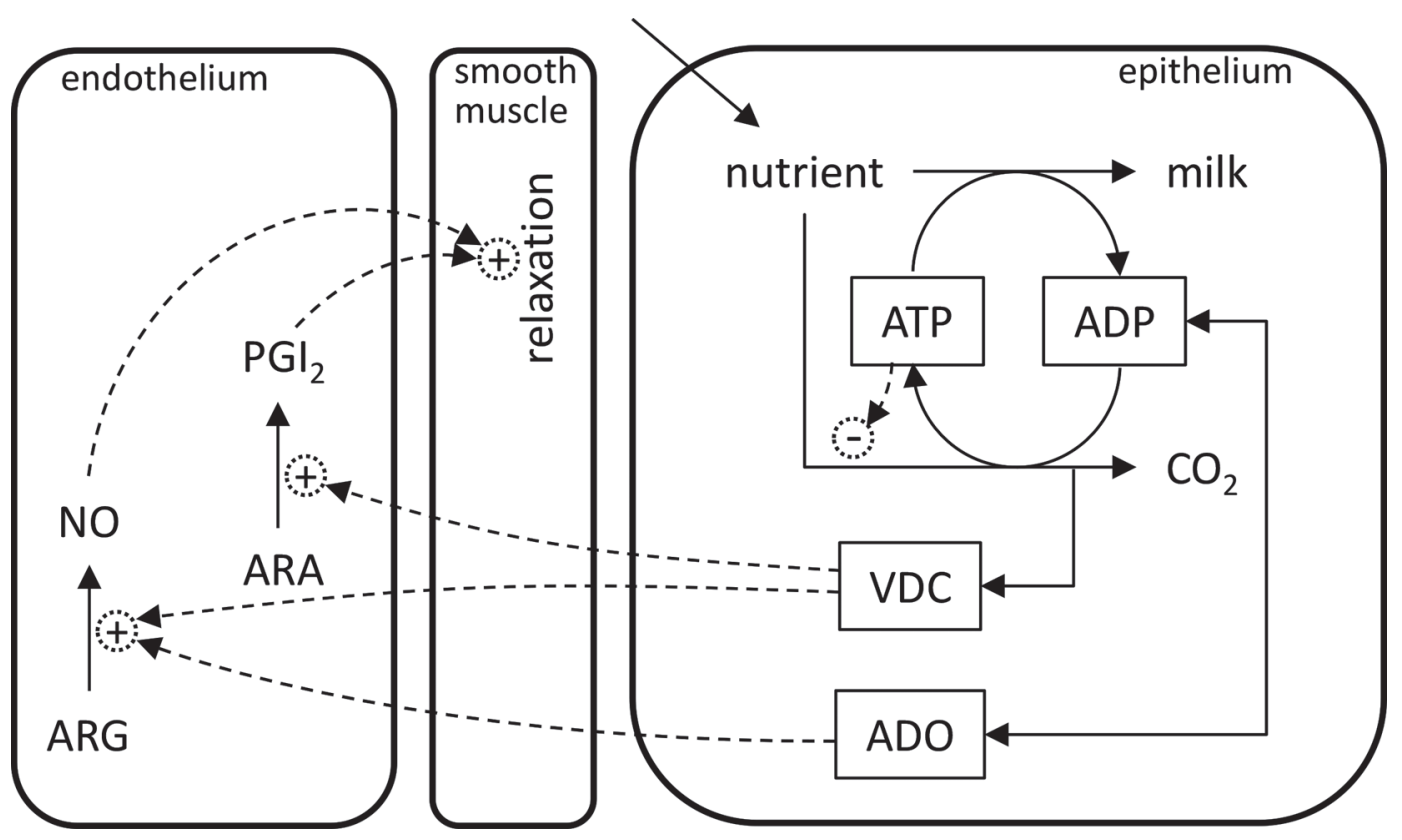

Figure 1. Proposed model of link between metabolic activity of mammary tissue and blood flow rate (adapted from Cieslar et al., 2014). Solid arrows represent mass flux and dashed arrows represent effector mechanisms; + and - represent activation and inhibition, respectively. ADO = adenosine; $\mathrm{ARA}=$ arachidonic acid; $\mathrm{ARG}=$ arginine; $\mathrm{NO}=$ nitric oxide; $\mathrm{PGI}_{2}=$ prostacyclin; $\mathrm{VDC}=$ vasodilatory compounds. 
for AA transporters have been found to increase in expression in the mammary glands of different species at the onset of lactation (Manjarin et al., 2014). Similarly, stimulation of milk protein yield with GH injection was associated with an increased expression of the SLC3A2 AA transporter in mammary tissue of cows (Sciascia et al., 2015). Thus, although expression of several other AA transporters was not affected by GH (Sciascia et al., 2015), and manipulations of dietary EAA supplies to lactating sows that have improved EAA utilization by the mammary glands have not been associated with altered AA transporter expression (Manjarín et al., 2012; Huber et al., 2016), some evidence indicates that control of AA transport is at least part of a coordinated effort to regulate AA utilization by the mammary glands. Nevertheless, the control of milk protein production has a much larger effect.

\section{CONTROL OF MILK PROTEIN YIELD}

Milk protein synthesis in ruminants is a process of translation of mRNA for the milk protein genes CSN1S1, CSN1S2, CSN2, CSN3, LALBA, and BLG. There are 4 possible ways by which the total mammary rate of translation of these mRNA species can be affected. In individual cells, the level of expression of the milk protein genes may change, or efficiency of mRNA translation may be altered by phosphorylation of translation factors, or through regulation of the abundance of components of the translational apparatus in secretory cells. Finally, it is possible that a change in secretory cell number is responsible for nutritional modification of total mammary translation rate. These 4 possibilities will be considered in the following sections.

\section{Cellular Expression of Milk Protein Genes}

Milk protein genes are expressed in milk secretory cells under the control of insulin, prolactin, and cortisol signals (Rosen et al., 1999). The increase in circulating prolactin concentrations during late pregnancy and at the onset of lactation stimulates expression of milk protein genes. Energy restriction of transition cows with a high-forage diet for 11 wk decreased milk protein yield from 1,001 to $547 \mathrm{~g} / \mathrm{d}$ and expression of mammary csn3 and lalba relative to a reference gene was also decreased (Dessauge et al., 2011). However, Boutinaud et al. (2008) found no effect on mammary csn 3 and lalba expression when energy was restricted $30 \%$ and milk protein yield dropped $22 \%$. Moreover, a hyperinsulinemic euglycemic clamp for $48 \mathrm{~h}$, which increases milk protein yield, was not accompanied by an increase in $\operatorname{csn} 1$ expression (Gross et al., 2015), and adding rapeseed to goat diets caused milk protein yield to drop $10 \%$ but had no effect on mammary lalba, csn2, or csn3 expression (Ollier et al., 2009). These pieces of evidence suggest that $\mathrm{NE}_{\mathrm{L}}$ sources and supplies do not generally affect expression of milk protein genes, but affect milk protein synthesis primarily through other mechanisms. Similarly, a lack of effect of enhanced EAA supply on mammary expression of csn2 and lalba, even though milk protein yield increased $256 \mathrm{~g} / \mathrm{d}$ (Nichols et al., 2017), suggests that a change in milk protein gene expression is not responsible for MP-induced changes in milk protein yield either.

\section{Phosphorylation of Translation Factors}

Translation of mRNA follows a sequence of initiation, elongation, and termination and is carried out by an array of ribosomes, translation factors, and ancillary enzymes. The rate at which proteins are produced by translation is not affected by the rate of elongation, which only affects the time delay between initiation and termination (El-Haroun et al., 2010), unless elongation is so slow as to interfere with initiation (Connors et al., 2008). Multiple signaling cascades influence the activity of participants in translation initiation and thereby regulate the efficiency of translation. These include the mechanistic target of rapamycin complex 1 (mTORC1), integrated stress response (ISR), and glycogen synthase kinase-3 (GSK3) pathways (Figure 2).

In brief, mTORC1 is an intracellular complex of proteins that is activated by growth factors like insulin and IGF-1, intracellular AA, particularly Leu, and intracellular energy charge (i.e., ATP:AMP ratio) to phosphorylate a kinase of the ribsomal protein S6 (S6K1) and a binding protein of the eukaryotic initiation factor $4 \mathrm{E}$ (4EBP1). Phosphorylation of 4EBP1 and S6K1 accelerates the initiation of mRNA translation, which results in faster protein synthesis (Wullschleger et al., 2006). Thus, via this one protein complex, a cell exposed to a growth signal from elsewhere in the body, such as IGF1, can decide based on its own intracellular AA and energy status, to what degree it should respond to the signal by increasing its rate of global protein synthesis, growth, and progression to mitosis. Signaling through mTORC1 is responsible for the increase in protein synthesis that occurs in muscle after consumption of a meal (Kimball et al., 2000). This mTORC1 signaling is also how protein drinks increase muscle mass in body builders (Hulmi et al., 2009).

The ISR pathway of translational control interferes with initiation by phosphorylating the $\alpha$ subunit of eukaryotic initiation factor 2 (eIF2), which then be- 


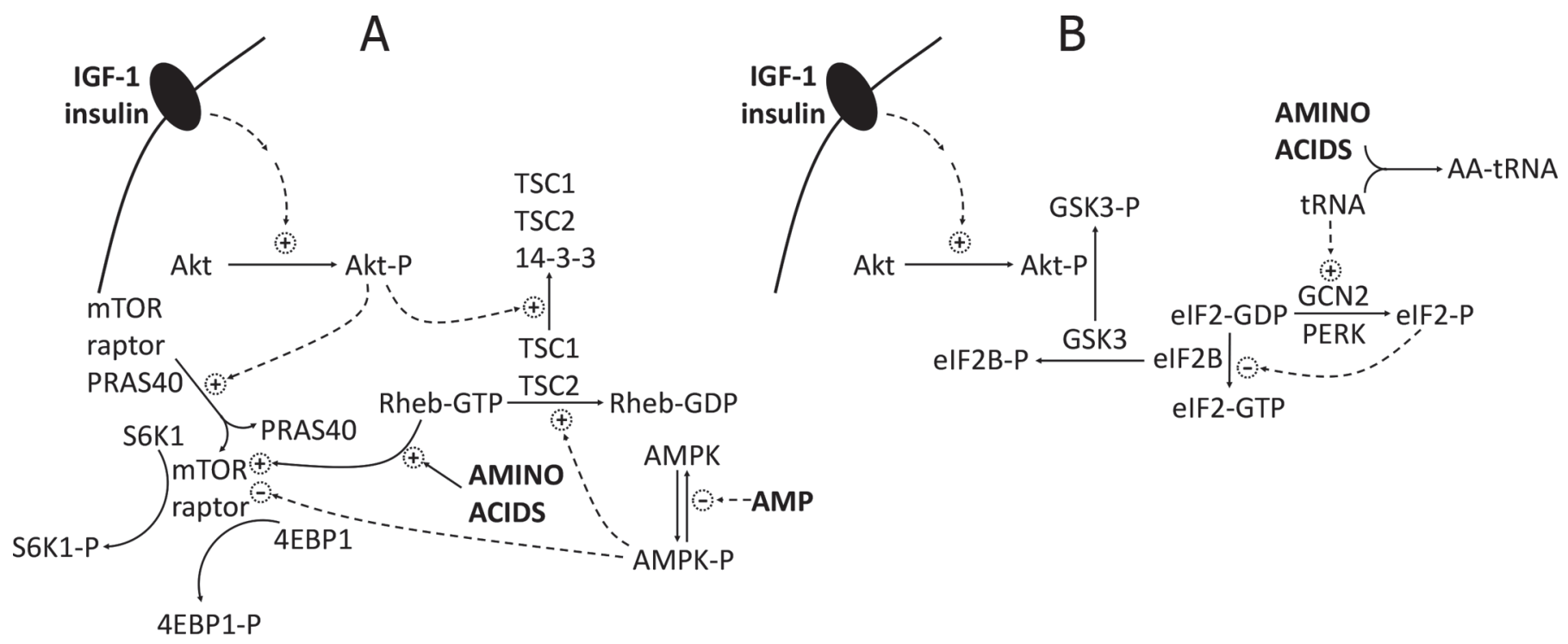

Figure 2. Mechanistic target of rapamycin (mTOR) complex 1 (A) and integrated stress response and glycogen synthase kinase-3 (GSK3) signaling pathways (B) that control initiation of mRNA translation. Solid arrows represent mass flux and dashed arrows represent effector mechanisms; + and - represent activation and inhibition, respectively; -P represents phosphorylation. 4EBP1 = eukaryotic initiation factor (eIF) 4E-binding protein 1; 14-3-3 = 14-3-3 protein; Akt = protein kinase B; AMPK = adenosine monophosphate-activated protein kinase; GCN2 = general control nondepressible 2; GDP = guanosine diphosphate; GTP = guanosine triphosphate; PERK = protein kinase R-like endoplasmic reticulum kinase; PRAS40 = 40-kDa proline-rich Akt substrate; raptor = regulatory associated protein of $\mathrm{mTOR}$; Rheb $=$ Ras homolog enriched in brain; $\mathrm{S} 6 \mathrm{~K} 1=70-\mathrm{kDa}$ ribosomal protein $\mathrm{S} 6$ kinase 1; tRNA = transfer RNA; TSC = tuberous sclerosis complex.

comes an inhibitor of the eIF2B enzyme that activates eIF2 by replacing GDP with GTP (Figure 2). General control nonderepressible 2 is an eIF2 $\alpha$ kinase that is activated by free tRNA that may accumulate when a single EAA is in deficient supply, and protein kinase R-like endoplasmic reticulum (ER) kinase (PERK) is another eIF2 $\alpha$ kinase that is activated by misfolded proteins in the endoplasmic reticulum (Proud, 2005). The ISR pathway is considered responsible for slower protein synthesis in tissues of growing animals fed diets deficient in a single EAA (Sikalidis and Stipanuk, 2010).

Activation of protein kinase B (Akt) by insulin or IGF-1 causes mTORC1-independent phosphorylation and inhibition of GSK3 (Proud, 2005), which is a negative regulator of eIF2B activity through phosphorylation of the catalytic eIF2B $\varepsilon$ subunit (Figure 2). Furthermore, translation of the mRNA for eIF2B $\varepsilon$ is stimulated by mTORC1 activation (Kubica et al., 2008). Increased abundance and activity of eIF2B $\varepsilon$ contribute to the anabolic state of skeletal muscle induced by resistance exercise (Kubica et al., 2005; Burd et al., 2010; Mayhew et al., 2011).

The mTORC1, ISR, and GSK3 networks stand as suitable candidates to explain nutritional effects on milk protein yield in dairy cows. The lactogenic hormones prolactin, insulin, and IGF-1 stimulate mTORC1 in mammary epithelial cells in vitro, as do many EAA, especially Leu, and intracellular energy state (Barash, 1999; Moshel et al., 2006; Burgos and Cant, 2010; Appuhamy et al., 2012; Burgos et al., 2013; Arriola Apelo et al., 2014a). Essential AA downregulate the ISR in mammary cells (Appuhamy et al., 2011, 2012). Addition of any one of several EAA to mammary cell culture media can stimulate mammary mTORC1 signaling (Appuhamy et al., 2012; Arriola Apelo et al., 2014a), which fits with the observations in vitro (Clark et al., 1978; Arriola Apelo et al., 2014b) and in vivo (Schwab et al., 1976; Hanigan et al., 2000; Weekes et al., 2006; Liu et al., 2017) of multiple AA affecting milk protein synthesis. Given that mammary mTORC1 and ISR networks respond to hormones relaying information about the physiological and nutritional state of the cow, and also respond to AA concentrations in the extracellular fluid, it is reasonable to hypothesize that these networks are the mechanism by which MP, glucose, and insulin stimulate milk protein yield in lactating cows.

When Toerien et al. (2010) infused fasted cows i.v. for $7 \mathrm{~h}$ with a mixture of all 10 EAA plus glucose, or glucose by itself, milk protein yield was stimulated. Both of the glucose-containing infusates caused a decrease in phosphorylation of mammary eIF $2 \alpha$, which is stimulatory to protein synthesis and could be responsible for the higher milk protein yield. The EAA-con- 
taining infusate also stimulated mammary mTORC1 signaling as evidenced by S6K1 phosphorylation state. Similarly, infusing casein plus starch for $36 \mathrm{~h}$ into the abomasum of cows fed at $70 \%$ of ad libitum intake stimulated mammary mTORC1, and milk protein yield increased by $146 \mathrm{~g} / \mathrm{d}$ (Rius et al., 2010). The relationship between mammary translational signaling and milk protein yield does not appear to hold up following longer infusions or treatments. Five days of abomasal infusion of all 10 EAA increased milk protein yield by 150 to $250 \mathrm{~g} / \mathrm{d}$ (Doelman et al., 2015a,b; Nichols et al., 2016), depending on the dose, but mammary mTORC1 activity was elevated at the end of $5 \mathrm{~d}$ in only 1 of those experiments (Doelman et al., 2015a). Furthermore, AA infusates devoid of one EAA, either His, Met, Phe, or Lys, stimulated mammary mTORC1 activity after 5 $\mathrm{d}$ but did not affect milk protein yields (Doelman et al., 2015a,b). According to phosphorylation states of eIF $2 \alpha$, the mammary ISR did not account for the lack of a milk protein response to imbalanced amino acid infusions. After 4 wk on a $50 \%$ forage diet, compared with the same length of time on an isonitrogenous $70 \%$ forage diet, cows produced $197 \mathrm{~g} / \mathrm{d}$ more milk protein, but there were no differences in phosphorylation state of mammary mTORC1 and ISR participants (Bajramaj et al., 2017). All of these results suggest that mechanisms other than phosphorylation of translation factors are responsible for long-term nutritional effects on milk protein yield.

It is worthwhile to consider whether kinase and phosphatase activities in tissue samples between excision and freezing of tissue in liquid $\mathrm{N}_{2}$ may be ablating treatment differences in phosphorylation states of signaling proteins. All of the above mammary samples were obtained by core biopsy and snap frozen within 2 min. Two minutes is generally considered a short time period for stability of phosphoproteins and concerns are generally related to pre-freezing time delays of greater than 10 min (Espina et al., 2008; Gündisch et al., 2013). Baker et al. (2005) reported a half-life of 20 min for phospho-Akt (Ser473) in human colon tumor xenografts that were maintained at room temperature after excision. According to this decay parameter, the loss in phosphorylation at 2 min would be $7 \%$, which is not large enough to prevent detection of differences between treatments that affect milk protein yields by upwards of $30 \%$.

\section{Cellular Abundance of Translation Machinery}

Because translation occurs on ribosomes and the majority of RNA in a cell is ribosomal, an increase in rRNA expression or RNA mass in cells is expected to result in faster rates of protein synthesis (Lobley, 1993). The onset of lactation in many species is associated with an increase in the RNA:DNA ratio of the mammary epithelium (Akers et al., 1981; Knight and Peaker, 1982), indicating a greater capacity for protein synthesis. The lactogenic hormone prolactin appears primarily responsible for inducing this increase in mammary RNA:DNA in rodents and ruminants alike (Baldwin and Martin, 1968; Akers et al., 1981; Forsyth and Lee, 1993). Nutritional effects on mammary epithelial RNA: DNA have not been as well characterized but there is little evidence to suggest translational capacity of mammary cells is affected by nutrition of the lactating dam. Fasting mice for $24 \mathrm{~h}$ starting on d 1 of lactation caused mammary RNA:DNA to decrease but fasting the same length of time on d 7 had no effect (Knight and Peaker, 1982), suggesting that an increase in RNA: DNA is part of the process of lactogenesis and is not nutritionally responsive once lactation is established. Similarly, induction of lactation in nonpregnant goats with steroid and cortisol injections resulted in a rate of milk production that was only $55 \%$ of that in goats that underwent pregnancy and parturition but mammary RNA:DNA was not different between the groups (Chilliard et al., 1986). Growth hormone injection into cows for $6 \mathrm{~d}$, which stimulated milk production $3.5 \mathrm{~kg} / \mathrm{d}$ or $42 \%$ over control, did not affect mammary RNA:DNA (Sciascia et al., 2013). However mRNA expression level of $18 \mathrm{~S}$ rRNA (rna18s5) relative to reference genes was upregulated (Sciascia et al., 2013), so there may have been a greater number of ribosomes per cell that was not detected with the RNA:DNA measurement. In rats fed an excess of Leu, which stimulated milk production $50 \%$, the mammary RNA:DNA ratio was not affected (Chugh et al., 1989). Similarly, 5-d infusions of EAA into cows, which increased milk protein yield $256 \mathrm{~g} / \mathrm{d}$ or $29 \%$ over control, had no effect on relative expression in mammary tissue of the rRNA precursor rna $45 s 5$ or rps6, rps9, and rpl15 coding for proteins of the small and large ribosomal subunits (Nichols et al., 2017).

The translation factors whose phosphorylation and activity states have been subjected to intense scrutiny may also be regulated at the level of gene and protein expression but this possibility has not received widespread attention. Perhaps best characterized is the protein abundance of eIF2B $\varepsilon$, where translation of mRNA encoding this catalytic subunit of the eIF2B enzyme that carries out activation of eIF2 is upregulated by mTORC1 activation (Kubica et al., 2008), and polyubiquitinylation targets the subunit for proteasome-mediated degradation (Tuckow et al., 2013). The abundance of eIF2B $\varepsilon$ exerts a degree of control over global protein synthesis rate as evidenced by overex- 
pression studies (Hardt et al., 2004). Abundance of the $\mathrm{eIF} 2 \mathrm{~B} \varepsilon$ protein increases in skeletal muscle $16 \mathrm{~h}$ following a bout of resistance exercise (Kubica et al., 2005; Fluckey et al., 2006) and the magnitude of the increase is positively related to how much myofiber hypertrophy will occur over the next several weeks (Mayhew et al., 2011). In mammary tissue, eIF2B $\varepsilon$ abundance has been found to increase after $5 \mathrm{~d}$ of infusion of EAA mixtures, including those that do not stimulate milk protein yield because of a lack of a single EAA (Doelman et al., 2015a,b). Thus, eIF2B $\varepsilon$ abundance appears to be nutritionally responsive in mammary tissue but it does not exert control over the rate of milk protein synthesis under conditions of single EAA deficiency.

Cellular abundance of the mTORC1 target S6K1 in mammary tissue also appears to be responsive to nutritional manipulation. We have observed an increase in mammary S6K1 abundance after $5 \mathrm{~d}$ of abomasal EAA infusion into cows (Doelman et al., 2015b; Nichols et al., 2017) and a decrease after 6 d of i.v. glucose infusion into cows (Curtis et al., 2014). Growth hormone injection into cows also increased mammary abundance of S6K1 (Sciascia et al., 2013). The expression of rps6kb1 mRNA was not affected by EAA or glucose infusion (Nichols et al., 2017). In fact, expression of this mRNA is so stable across cows, periods, and treatments that it has been selected by ANOVA as the best mRNA for normalization of gene expression data in mammary tissue samples (Nichols et al., 2017). The discrepancy between nutritional effects on mRNA and protein expression of S6K1 may relate to degradation of the S6K1 protein when apoptosis is activated (Dhar et al., 2009; Piedfer et al., 2013). The regulation of S6K1 protein abundance deserves further study.

Sciascia et al. (2013) observed an increase in mammary abundance of eIF4E due to $6 \mathrm{~d}$ of GH treatment of lactating cows and proposed that IGF-1-mediated, mitogen-activated protein kinase signaling stimulated eIF4E translation. In cows infused for $5 \mathrm{~d}$ with 1,126 $\mathrm{g} / \mathrm{d}$ of EAA, we did not observe a change in mammary expression of the eiffe mRNA (Nichols et al., 2017), but this does not rule out a potential effect on eIF4E protein abundance.

\section{Number of Milk Secretory Cells}

The total number of terminally differentiated milk secretory cells in the udder of a cow depends on 3 aspects: mammary epithelial cell proliferation, differentiation and death. The process of cell growth and division can be separated into G1, synthesis, G2, and mitosis phases (Morgan, 2007). During the G1 phase, a newly formed daughter cell grows in size, which involves protein, lipid, and RNA synthesis and accumulation. Replication of DNA occurs in the synthesis phase. The cell continues to grow in size in the gap between synthesis and mitosis phases called the G2 phase. Finally, the mother cell divides into 2 daughter cells during the mitosis phase, which involves nuclear and cytoplasmic division. Cells that are not cycling, such as the terminally differentiated milk secretory cell, are considered to be in a G0 phase. Genes that are preferentially expressed during the synthesis, G2 and mitosis phases of the cell cycle can be used to index the proliferative state of a sample of cells. Proliferation cell nuclear antigen (PCNA) is an accessory protein for DNA polymerase that plays an essential role in DNA replication during the synthesis phase (Galand and Degraef, 1989). Cyclin D1 is synthesized and accumulates in the nucleus of the cell and controls the transition from G1 to synthesis phase (Baldin et al., 1993). Expression of Ki-67 occurs during the synthesis, G2, and mitosis phases (Scholzen and Gerdes, 2000).

Epithelial cells that proliferate in the mammary glands are progenitor cells. Daughter cells of the proliferation must terminally differentiate to become milk secretory cells, which do not proliferate. Milk secretory cell differentiation requires development of the ER (Oka and Topper, 1971), which is the site of synthesis of milk fat globules, milk proteins, and the subunits of lactose synthase. Biogenesis of the ER is regulated by signaling pathways that were originally identified as part of the unfolded protein response (UPR) in ER-stressed cells (Figure 3). When unfolded proteins accumulate inside the ER, the chaperone binding protein $(\mathrm{BiP})$ dissociates from luminal domains of 3 sensors, PERK, activating transcription factor 6 (ATF6), and endoribonuclease inositol-requiring enzyme $1 \alpha$ (IRE1 $\alpha)$, causing PERK and IRE1 $\alpha$ to become phosphorylated and an ATF6f fragment to be cleaved from ATF6 (Hetz et al., 2015). Phosphorylated PERK phosphorylates eIF2 $\alpha$ to inhibit mRNA translation as part of the ISR pathway (Proud, 2005). Phosphorylation of eIF2 $\alpha$ paradoxically stimulates translation of $\mathrm{mRNA}$ for activating transcription factor 4 (ATF4), which increases expression of $\mathrm{C} /$ EBP homologous protein $(\mathbf{C H O P})$ and growth arrest and DNA damage-inducible 34 (GADD34), proteins that induce cell apoptosis if ER stress is not alleviated (Harding et al., 2000; Rutkowski et al., 2006). The ATF6f fragment promotes transcription of genes for ER-associated proteins, including X-box binding protein 1 (XBP1). Phosphorylated IRE1 $\alpha$ is an active RNase that splices a 26-base intron out of the $x b p 1$ mRNA, forming $x b p 1 s$, which is translated to XBP1 that activates transcription of genes related to ER biogenesis and secretory vesicle maturation (Davis et 
al., 2016). Stimulation of differentiation of secretory cells, such as $\beta$-cells of the pancreas, plasma cells of the immune system, and zymogen-producing cells of the gastric mucosa, involves suppression of the PERKATF4 arm of the UPR and stimulation of the ATF6 and IRE1 $\alpha$ arms (Rutkowski and Hegde, 2010).

Apoptosis is a process of programmed cell death that can be triggered by intrinsic or extrinsic signals. When a cell is under stress, including ER stress, and repair pathways cannot restore the cell to normal condition, the intermembrane of mitochondria is triggered to release proteins that activate the caspase family of proteases that carry out destruction of the entire cell (Tang et al., 2008). For example, the pro-apoptotic transcription factor CHOP, whose expression is upregulated by the PERK-ATF4 arm of the UPR, leads to cell death by stimulating transcription of genes for the pro-apoptotic mitochondrial protein Bax and inhibiting transcription of the anti-apoptotic Bcl-2 (Sano and Reed, 2013).

The decline in daily milk yield with advancing lactation after peak is due primarily to a decrease in secretory cell number, and not a change in milk-synthesizing activity per cell (Capuco et al., 2001). Proliferation and death rates of mammary epithelial cells, assessed through expression of Ki-67 and DNA-nick staining, do not appear to change as lactation progresses past peak, but death proceeds at a faster rate than proliferation so that cell number declines (Capuco et al., 2001). Expression of genes coding for proteins involved in ER biogenesis, including binding protein and ATF4, were higher in mammary glands of cows during early versus late lactation or the dry period (Invernizzi et al., 2012), suggesting that differentiation is faster in early lactation. Mammary cell turnover and differentiation are also affected by nutrition of the dam. The decrease in milk yield when $\mathrm{NE}_{\mathrm{L}}$ intake of dairy cows is restricted appears to be due to a decrease in milk secretory cell number (Nørgaard et al., 2008; Dessauge et al., 2011). In mammary samples collected after $24 \mathrm{~d}$ on high- or low-energy diets, Nørgaard et al. (2005) found that the proportion of cells staining positive for PCNA was lower on the low-energy diet, indicating negative effects on cell proliferation. In contrast, Dessauge et al. (2011) found that a $20 \%$ feed restriction did not affect mammary epithelial cell proliferation as indicated by PCNA staining after 9 wk of treatment, but instead, all the markers of cell apoptosis, BAD, caspase 3, cathepsin B, IGFBP-5, and calpain, increased. After $5 \mathrm{~d}$ of infusing

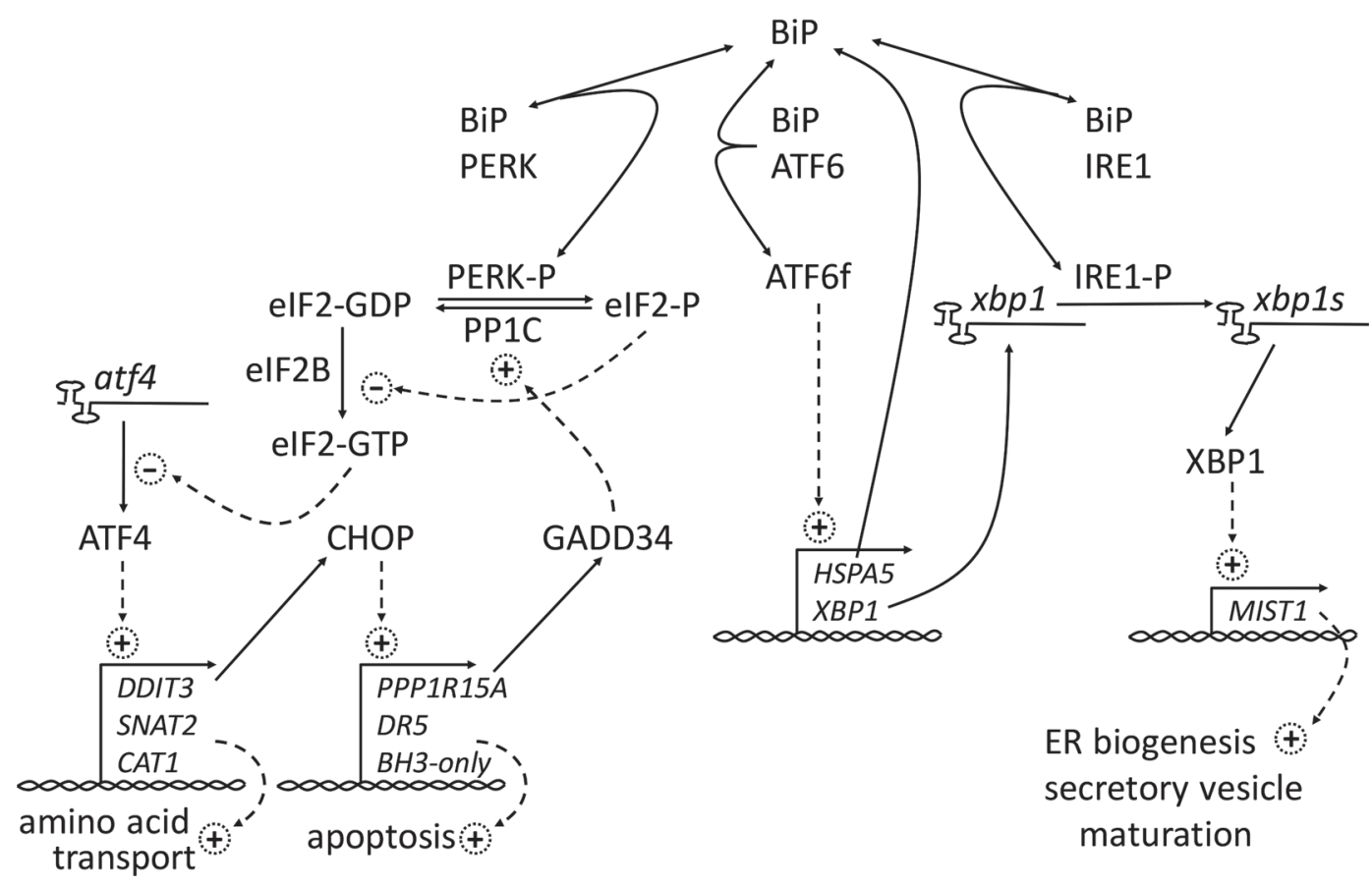

Figure 3. Arms of the unfolded protein response that are suppressed (PERK) and activated (ATF6 and IRE1) in secretory cell differentiation. Solid arrows represent mass flux and dashed arrows represent effector mechanisms; + and - represent activation and inhibition, respectively; $-\mathrm{P}$ represents phosphorylation. $\mathrm{ATF}=$ activating transcription factor; $\mathrm{ATF} 6 \mathrm{f}=\mathrm{ATF} 6$ fragment; $\mathrm{BiP}=$ binding protein; $\mathrm{CHOP}=\mathrm{C} / \mathrm{EBP}$ homologous protein; eIF = eukaryotic initiation factor; $\mathrm{ER}=$ endoplasmic reticulum; GADD34 = growth arrest and DNA damage-inducible 34; IRE1 = endoribonuclease inositol-requiring enzyme 1 ; PERK = protein kinase R-like endoplasmic reticulum kinase; PP1C = protein phosphatase $1 \mathrm{C}$; XBP1 = X-box binding protein-1; xbp1s = XBP1 splice fragment. 
a complete mix of EAA abomasally into cows, which increased milk yield $4.1 \mathrm{~kg} / \mathrm{d}$, Nichols et al. (2017) did not find any effect on mammary expression of genes related to cell proliferation or death, but there was an increased expression of the spliced form of the $x b p 1$ mRNA and decreased expression of ddit3 and ppp1r15a mRNAs encoding CHOP and GADD34, respectively. This pattern of gene expression is consistent with greater secretory cell differentiation (Figure 3) and suggests that ER biogenesis is involved in long-term nutritional regulation of milk protein yield. This possibility is a reminder that the number of secretory cells in the udder is a consequence not only of proliferation and death rates of the mammary epithelium, but also involves differentiation of the secretory phenotype in individual cells.

\section{CONCLUSIONS}

Net mammary uptake of AA is regulated by control of the rates of milk protein synthesis, tissue protein accretion, and catabolism. Control of milk protein synthesis is the main contributor because over $90 \%$ of net AA uptake is sequestered in milk protein. The stimulatory effect of MP supply on milk protein yield can be understood as proceeding as follows: accelerated EAA delivery to the mammary glands due to higher concentrations in circulation causes faster unidirectional uptake of EAA, activating milk protein synthesis, which increases retention of the arterial influx and allows less to be returned to the venous circulation, thereby increasing net mammary uptake of EAA. Several pieces of evidence indicate that the early protein synthetic response of mammary epithelial cells to an increase in EAA, insulin, or IGF-1 concentrations is mediated by mTORC1, ISR, and GSK3 signaling pathways. Activation of these pathways does not appear to be maintained after several days of exposure to such stimuli in vivo. Acute stimulation of protein synthesis may be expected to hasten progression through G1 and G2 phases of the cell cycle of mammary progenitor cells and, consequently, faster proliferation rates or greater numbers of cells expressing proliferation markers in mammary tissue samples. In an experiment where EAA supply to the mammary glands increased milk protein yield $256 \mathrm{~g} / \mathrm{d}$, there was no change in mammary expression of milk protein mRNA, phosphorylation state of mammary translation factors, protein and mRNA abundances of components of the translational machinery, or mRNA markers of cell proliferation and death (Nichols et al., 2017). The only mRNA markers that were affected, of the candidates evaluated, were those related to ER biogenesis. Stronger and more direct measures of the differentiation status of the mammary epithelium, and connections to early activation of translation initiation, should be sought.

\section{ACKNOWLEDGMENTS}

Research funding was provided by NSERC Canada (Ottawa, Canada) and the Ontario Ministry of Agriculture, Food and Rural Affairs (Guelph, Canada). Sponsorship of the ADSA Lactation Symposium by Balchem (New Hampton, NY) and Phibro Animal Health Corp. (Teaneck, NJ) is gratefully acknowledged.

\section{REFERENCES}

Akers, R. M., D. E. Bauman, A. V. Capuco, G. T. Goodman, and H. A. Tucker. 1981. Prolactin regulation of milk secretion and biochemical differentiation of mammary epithelial cells in periparturient cows. Endocrinology 109:23-30.

Appuhamy, J. A. D. R. N., A. Bell, W. A. D. Nayananjalie, J. Escobar, and M. D. Hanigan. 2011. Essential amino acids regulate both initiation and elongation of mRNA translation independent of insulin in MAC-T cells and bovine mammary tissue slices. J. Nutr. 141:1209-1215.

Appuhamy, J. A. D. R. N., N. A. Knoebel, W. A. D. Nayananjalie, J. Escobar, and M. D. Hanigan. 2012. Isoleucine and leucine independently regulate mTOR signaling and protein synthesis in MAC-T cells and bovine mammary tissue slices. J. Nutr. 142:484-491.

Arriola Apelo, S. I., L. M. Singer, X. Y. Lin, M. L. McGilliard, N. R. St-Pierre, and M. D. Hanigan. 2014a. Isoleucine, leucine, methionine, and threonine effects on mammalian target of rapamycin signaling in mammary tissue. J. Dairy Sci. 97:1047-1056.

Arriola Apelo, S. I., L. M. Singer, W. K. Ray, R. F. Helm, X. Y. Lin, M. L. McGilliard, N. R. St-Pierre, and M. D. Hanigan. 2014b. Casein synthesis is independently and additively related to individual essential amino acid supply. J. Dairy Sci. 97:2998-3005.

Bajramaj, D. L., R. V. Curtis, J. J. M. Kim, M. Corredig, J. Doelman, T. C. Wright, V. R. Osborne, and J. P. Cant. 2017. Addition of glycerol to lactating cow diets stimulates milk protein yield to a greater extent than addition of corn grain. J. Dairy Sci. 100:6139-6150.

Baker, A. F., T. Dragovich, N. T. Ihle, R. Williams, C. Fenoglio-Preiser, and G. Powis. 2005. Stability of phosphoprotein as a biological marker of tumor signaling. Clin. Cancer Res. 11:4338-4340.

Baldin, V., J. Lukas, M. J. Marcote, M. Pagano, and G. Draetta. 1993. Cyclin D1 is a nuclear protein required for cell cycle progression in $\mathrm{G}_{1}$. Genes Dev. 7:812-821.

Baldwin, R. L., and R. J. Martin. 1968. Effects of hypophysectomy and several hormone replacement therapies upon patterns of nucleic acid and protein synthesis and enzyme levels in lactating rat mammary glands. J. Dairy Sci. 51:748-753.

Barash, I. 1999. Prolactin and insulin synergize to regulate the translation modulator PHAS-I via mitogen-activated protein kinaseindependent but wortmannin- and rapamycin-sensitive pathway. Mol. Cell. Endocrinol. 155:37-49.

Bequette, B. J., M. D. Hanigan, A. G. Calder, C. K. Reynolds, G. E. Lobley, and J. C. MacRae. 2000. Amino acid exchange by the mammary gland of lactating goats when histidine limits milk production. J. Dairy Sci. 83:765-775.

Bequette, B. J., C. E. Kyle, L. A. Crompton, V. Buchan, and M. D. Hanigan. 2001. Insulin regulates milk production and mammary gland and hind-leg amino acid fluxes and blood flow in lactating goats. J. Dairy Sci. 84:241-255.

Böger, R. H., S. M. Bode-Böger, R. P. Brandes, L. Phivthong-ngam, M. Böhme, R. Nafe, A. Mügge, and J. C. Frölich. 1997. Dietary 
L-arginine reduces the progression of atherosclerosis in cholesterolfed rabbits. Circulation 96:1282-1290.

Boutinaud, M., M. H. Ben Chedly, E. Delamaire, and J. GuinardFlament. 2008. Milking and feed restriction regulate transcripts of mammary epithelial cells purified from milk. J. Dairy Sci. 91:988998.

Burd, N. A., A. M. Holwerda, K. C. Selby, D. W. West, A. W. Staples, N. E. Cain, J. G. A. Cashaback, J. R. Potvin, S. K. Baker, and S. M. Phillips. 2010. Resistance exercise volume affects myofibrillar protein synthesis and anabolic signalling molecule phosphorylation in young men. J. Physiol. 588:3119-3130.

Burgos, S. A., and J. P. Cant. 2010. IGF-I stimulates protein synthesis by enhanced signaling through mTORC1 in bovine mammary epithelial cells. Domest. Anim. Endocrinol. 38:211-221.

Burgos, S. A., J. J. M. Kim, M. Dai, and J. P. Cant. 2013. Energy depletion of bovine mammary epithelial cells activates AMPK and suppresses protein synthesis through inhibition of mTORC1 signaling. Horm. Metab. Res. 45:183-189.

Cant, J. P., R. Berthiaume, H. Lapierre, P. H. Luimes, B. W. McBride, and D. Pacheco. 2003. Responses of the bovine mammary glands to absorptive supply of single amino acids. Can. J. Anim. Sci. 83:341-355.

Cant, J. P., E. J. DePeters, and R. L. Baldwin. 1993. Mammary uptake of energy metabolites in dairy cows fed fat and its relationship to milk protein depression. J. Dairy Sci. 76:2254-2265.

Cant, J. P., T. G. Madsen, and S. R. L. Cieslar. 2016. Predicting extraction and uptake of arterial energy metabolites by the mammary glands of lactating cows when blood flow is perturbed. J. Dairy Sci. 99:718-732.

Cant, J. P., D. R. Trout, F. Qiao, and N. G. Purdie. 2002. Milk synthetic response of the bovine mammary gland to an increase in the local concentration of arterial glucose. J. Dairy Sci. 85:494-503.

Capuco, A. V., D. L. Wood, R. Baldwin, K. McLeod, and M. J. Paape. 2001. Mammary cell number, proliferation, and apoptosis during a bovine lactation: Relation to milk production and effect of bST. J. Dairy Sci. 84:2177-2187.

Cardounel, A. J., H. Cui, A. Samouilov, W. Johnson, P. Kearns, A.-L. Tsai, V. Berka, and J. L. Zweier. 2007. Evidence for the pathophysiological role of endogenous methylarginines in regulation of endothelial no production and vascular function. J. Biol. Chem. 282:879-887.

Chilliard, Y., C. DeLouis, M. C. Smith, D. Sauvant, and P. MorandFehr. 1986. Mammary metabolism in the goat during normal or hormonally-induced lactation. Reprod. Nutr. Dev. 26:607-615.

Chugh, K., B. Lal, and A. S. Saini. 1989. Effect of feeding excess leucine diet on nursing performance and mammary gland development in rats. Nutr. Res. 9:233-236.

Cieslar, S. R. L., T. G. Madsen, N. G. Purdie, D. R. Trout, V. R. Osborne, and J. P. Cant. 2014. Mammary blood flow and metabolic activity are linked by a feed-back mechanism involving nitric oxide synthesis. J. Dairy Sci. 97:2090-2100.

Clark, R. M., P. T. Chandler, and C. S. Park. 1978. Limiting amino acids for milk protein synthesis by bovine mammary cells in culture. J. Dairy Sci. 61:408-413.

Connors, M. T., D. P. Poppi, and J. P. Cant. 2008. Protein elongation rates in tissues of growing and adult sheep. J. Anim. Sci. $86: 2288-2295$.

Curtis, R. V., J. J. M. Kim, D. L. Bajramaj, J. Doelman, V. R. Osborne, and J. P. Cant. 2014. Decline in mammary translational capacity during intravenous glucose infusion into lactating dairy cows. J. Dairy Sci. 97:430-438.

Daniel, J. B., N. C. Friggens, P. Chapoutot, H. Van Laar, and D. Sauvant. 2016. Milk yield and milk composition responses to change in predicted net energy and metabolizable protein: A meta-analysis. Animal 10:1975-1985.

Davis, K. R., S. L. Giesy, Q. Long, C. S. Krumm, K. J. Harvatine, and Y. R. Boisclair. 2016. XBP1 regulates the biosynthetic capacity of the mammary gland during lactation by controlling epithelial expansion and endoplasmic reticulum formation. Endocrinology $157: 417-428$
Dessauge, F., V. Lollivier, B. Ponchon, R. Bruckmaier, L. Finot, S. Wiart, E. Cutullic, C. Disenhaus, S. Barbey, and M. Boutinaud. 2011. Effects of nutrient restriction on mammary cell turnover and mammary gland remodeling in lactating dairy cows. J. Dairy Sci. 94:4623-4635.

Deussen, A., V. Ohanyan, A. Jannasch, L. Yin, and W. Chilian. 2012. Mechanisms of metabolic coronary flow regulation. J. Mol. Cell. Cardiol. 52:794-801

Dhar, R., S. D. Persaud, J. R. Mireles, and A. Basu. 2009. Proteolytic cleavage of p70 ribosomal S6 kinase by caspase-3 during DNA damage-induced apoptosis. Biochemistry 48:1474-1480.

Doelman, J., R. V. Curtis, M. Carson, J. J. M. Kim, J. A. Metcalf, and J. P. Cant. 2015a. Essential amino acid infusions stimulate mammary expression of eukaryotic initiation factor $2 \mathrm{~B} \varepsilon$ but milk protein yield is not increased during an imbalance. J. Dairy Sci. 98:4499-4508.

Doelman, J., J. J. M. Kim, M. Carson, J. A. Metcalf, and J. P. Cant. 2015b. Branched-chain amino acid and lysine deficiencies exert different effects on mammary translational regulation. J. Dairy Sci. 98:7846-7855.

Doepel, L., and H. Lapierre. 2011. Deletion of arginine from an abomasal infusion of amino acids does not decrease milk protein yield in Holstein cows. J. Dairy Sci. 94:864-873.

Dudzinski, D. M., J. Igarashi, D. Greif, and T. Michel. 2006. The regulation and pharmacology of endothelial nitric oxide synthase. Annu. Rev. Pharmacol. Toxicol. 46:235-276.

Eisemann, J. H., and G. B. Huntington. 1994. Metabolite flux across portal-drained viscera, liver, and hindquarters of hyperinsulinemic, euglycemic beef steers. J. Anim. Sci. 72:2919-2929.

El-Haroun, E. R., D. P. Bureau, and J. P. Cant. 2010. A mechanistic model of nutritional control of protein synthesis in animal tissues. J. Theor. Biol. 262:361-369.

Espina, V., K. H. Edmiston, M. Heiby, M. Pierobon, M. Sciro, B. Merritt, S. Banks, J. Deng, A. J. VanMeter, D. H. Geho, L. Pastore, J. Sennesh, E. F. Petricoin III, and L. A. Liotta. 2008. A portrait of tissue phosphoprotein stability in the clinical tissue procurement process. Mol. Cell. Proteomics 7:1998-2018.

Fluckey, J. D., M. Knox, L. Smith, E. E. Dupont-Versteegden, D Gaddy, P. A. Tesch, and C. A. Peterson. 2006. Insulin-facilitated increase of muscle protein synthesis after resistance exercise involves a MAP kinase pathway. Am. J. Physiol. Endocrinol. Metab. 290:E1205-E1211.

Forsyth, I. A., and P. D. Lee. 1993. Bromocriptine treatment of periparturient goats: Long-term suppression of prolactin and lack of effect on lactation. J. Dairy Res. 60:307-317.

Galand, P., and C. Degraef. 1989. Cyclin/PCNA immunostaining as an alternative to tritiated thymidine pulse labelling for marking $\mathrm{S}$ phase cells in paraffin sections from animal and human tissues. Cell Tissue Kinet. 22:383-392.

Gross, J. J., H. A. van Dorland, O. Wellnitz, and R. M. Bruckmaier. 2015. Glucose transport and milk secretion during manipulated plasma insulin and glucose concentrations and during LPSinduced mastitis in dairy cows. J. Anim. Physiol. Anim. Nutr. (Berl.) 99:747-756.

Guinard, J., and H. Rulquin. 1995. Effects of graded amounts of duodenal infusions of methionine on the mammary uptake of major milk precursors in dairy cows. J. Dairy Sci. 78:2196-2207.

Gündisch, S., K. Grundner-Culemann, C. Wolff, C. Schott, B. Reischauer, M. Machatti, D. Groelz, C. Schaab, A. Tebbe, and K.-F. Becker. 2013. Delayed times to tissue fixation result in unpredictable global phosphoproteome changes. J. Proteome Res. 12:44244434 .

Guo, C. L., Y. T. Li, X. Y. Lin, M. D. Hanigan, Z. G. Yan, Z. Y. Hu, Q. L. Hou, F. G. Jiang, and Z. H. Wang. 2017. Effects of graded removal of lysine from an intravenously infused amino acid mixture on lactation performance and mammary amino acid metabolism in lactating goats. J. Dairy Sci. 100:4552-4564.

Hanigan, M. D., J. France, L. A. Crompton, and B. J. Bequette. 2000 Evaluation of a representation of the limiting amino acid theory for milk protein synthesis. Pages 127-144 in Modelling Nutrient 
Utilization in Farm Animals. J. P. McNamara, J. France, and D. Beever, ed. CABI Publishing, Wallingford, UK

Harding, H. P., I. Novoa, Y. H. Zhang, H. Q. Zeng, R. Wek, M. Schapira, and D. Ron. 2000. Regulated translation initiation controls stress-induced gene expression in mammalian cells. Mol. Cell 6:1099-1108.

Hardt, S. E., H. Tomita, H. A. Katus, and J. Sadoshima. 2004. Phosphorylation of eukaryotic translation initiation factor $2 \mathrm{~B} \varepsilon$ by glycogen synthase kinase- $3 \beta$ regulates $\beta$-adrenergic cardiac myocyte hypertrophy. Circ. Res. 94:926-935.

Hellsten, Y., M. Nyberg, L. G. Jensen, and S. P. Mortensen. 2012. Vasodilator interactions in skeletal muscle blood flow regulation. J. Physiol. 590:6297-6305.

Hetz, C., E. Chevet, and S. A. Oakes. 2015. Proteostasis control by the unfolded protein response. Nat. Cell Biol. 17:829-838.

Huber, L., C. F. M. de Lange, C. W. Ernst, U. Krogh, and N. L. Trottier. 2016. Impact of improving dietary amino acid balance for lactating sows on efficiency of dietary amino acid utilization and transcript abundance of genes encoding lysine transporters in mammary tissue. J. Anim. Sci. 94:4654-4665.

Hulmi, J. J., J. Tannerstedt, H. Selänne, H. Kainulainen, V. Kovanen, and A. A. Mero. 2009. Resistance exercise with whey protein ingestion affects mTOR signaling pathway and myostatin in men. J. Appl. Physiol. 106:1720-1729.

Invernizzi, G., A. Naeem, and J. J. Loor. 2012. Short communication: Endoplasmic reticulum stress gene network expression in bovine mammary tissue during the lactation cycle. J. Dairy Sci. 95:25622566 .

Kimball, S. R., L. S. Jefferson, H. V. Nguyen, A. Suryawan, J. A. Bush, and T. A. Davis. 2000. Feeding stimulates protein synthesis in muscle and liver of neonatal pigs through an mTOR-dependent process. Am. J. Physiol. Endocrinol. Metab. 279:E1080-E1087.

Knight, C. H., and M. Peaker. 1982. Effects of fasting during mid pregnancy or early lactation on mammary development and milk yield in mice. J. Dairy Res. 49:567-575.

Krogh, U., N. Oksbjerg, A. C. Storm, T. Feyera, and P. K. Theil. 2017. Mammary nutrient uptake in multiparous sows fed supplementary arginine during gestation and lactation. J. Anim. Sci. 95:2517-2532.

Kubica, N., D. R. Bolster, P. A. Farrell, S. R. Kimball, and L. S. Jefferson. 2005. Resistance exercise increases muscle protein synthesis and translation of eukaryotic initiation factor $2 \mathrm{~B} \varepsilon$ mRNA in a mammalian target of rapamycin-dependent manner. J. Biol. Chem. 280:7570-7580.

Kubica, N., J. L. Crispino, J. W. Gallagher, S. R. Kimball, and L. S. Jefferson. 2008. Activation of the mammalian target of rapamycin complex 1 is both necessary and sufficient to stimulate eukaryotic initiation factor $2 \mathrm{~B} \varepsilon \mathrm{mRNA}$ translation and protein synthesis. Int. J. Biochem. Cell Biol. 40:2522-2533.

Linzell, J. L. 1974. Mammary blood flow and methods of identifying and measuring precursors of milk. Pages $143-225$ in Lactation: A Comprehensive Treatise. Vol. 1. B. L. Larson and V. R. Smith, ed. Academic Press, New York, NY.

Liu, G. M., M. D. Hanigan, X. Y. Lin, K. Zhao, F. G. Jiang, R. R. White, Y. Wang, Z. Y. Hu, and Z. H. Wang. 2017. Methionine, leucine, isoleucine, or threonine effects on mammary cell signaling and pup growth in lactating mice. J. Dairy Sci. 100:4038-4050.

Lobley, G. E. 1993. Species comparisons of tissue protein metabolism: Effects of age and hormonal action. J. Nutr. 123:337-343.

Mackle, T. R., D. A. Dwyer, K. L. Ingvartsen, P. Y. Chouinard, D. A. Ross, and D. E. Bauman. 2000. Effects of insulin and postruminal supply of protein on use of amino acids by the mammary gland of milk protein synthesis. J. Dairy Sci. 83:93-105.

Manjarin, R., B. J. Bequette, G. Wu, and N. L. Trottier. 2014. Linking our understanding of mammary gland metabolism to amino acid nutrition. Amino Acids 46:2447-2462.

Manjarín, R., V. Zamora, G. Wu, J. P. Steibel, R. N. Kirkwood, N. P. Taylor, E. Wils-Plotz, K. Trifilo, and N. L. Trottier. 2012. Effect of amino acids supply in reduced crude protein diets on performance, efficiency of mammary uptake, and transporter gene expression in lactating sows. J. Anim. Sci. 90:3088-3100.
Mayhew, D. L., T. A. Hornberger, H. C. Lincoln, and M. M. Bamman. 2011. Eukaryotic initiation factor 2B epsilon induces capdependent translation and skeletal muscle hypertrophy. J. Physiol. 589:3023-3037.

Morgan, D. O. 2007. The Cell Cycle: Principles of Control. New Science Press, London, UK.

Moshel, Y., R. E. Rhoads, and I. Barash. 2006. Role of amino acids in translational mechanisms governing milk protein synthesis in murine and ruminant mammary epithelial cells. J. Cell. Biochem. 98:685-700.

Nichols, K., J. Doelman, J. J. M. Kim, M. Carson, J. A. Metcalf, and J. P. Cant. 2017. Exogenous essential amino acids stimulate an adaptive unfolded protein response in the mammary glands of lactating cows. J. Dairy Sci. 100:5909-5921.

Nichols, K., J. J. M. Kim, M. Carson, J. A. Metcalf, J. P. Cant, and J. Doelman. 2016. Glucose supplementation stimulates peripheral branched-chain amino acid catabolism in lactating dairy cows during essential amino acid infusions. J. Dairy Sci. 99:1145-1160.

Nørgaard, J. V., A. Sørensen, M. T. Sørensen, J. B. Andersen, and K. Sejrsen. 2005. Mammary cell turnover and enzyme activity in dairy cows: Effects of milking frequency and diet energy density. J. Dairy Sci. 88:975-982

Nørgaard, J. V., P. K. Theil, M. T. Sørensen, and K. Sejrsen. 2008. Cellular mechanisms in regulating mammary cell turnover during lactation and dry period in dairy cows. J. Dairy Sci. 91:2319-2327.

NRC. 2001. Nutrient Requirements of Dairy Cattle. 7th rev. ed. Natl. Acad. Sci., Washington, DC.

Oka, T., and Y. J. Topper. 1971. Hormone-dependent accumulation of rough endoplasmic reticulum in mouse mammary epithelial cells in vitro. J. Biol. Chem. 246:7701-7707.

Ollier, S., C. Leroux, A. de la Foye, L. Bernard, J. Rouel, and Y. Chilliard. 2009. Whole intact rapeseeds or sunflower oil in highforage or high-concentrate diets affects milk yield, milk composition, and mammary gene expression profile in goats. J. Dairy Sci. 92:5544-5560.

Piedfer, M., S. Bouchet, R. Tang, C. Billard, D. Dauzonne, and B. Bauvois. 2013. p70S6 kinase is a target of the novel proteasome inhibitor 3,3'-diamino-4'-methoxyflavone during apoptosis in human myeloid tumor cells. Biochim. Biophys. Acta 1833:1316-1328.

Proud, C. G. 2005. eIF2 and the control of cell physiology. Semin. Cell Dev. Biol. 16:3-12.

Rigout, S., S. Lemosquet, A. Bach, J. W. Blum, and H. Rulquin. 2002. Duodenal infusion of glucose decreases milk fat production in grass silage-fed dairy cows. J. Dairy Sci. 85:2541-2550.

Rius, A. G., J. A. D. R. N. Appuhamy, J. Cyriac, D. Kirovski, O. Becvar, J. Escobar, M. L. McGilliard, B. J. Bequette, R. M. Akers, and M. D. Hanigan. 2010. Regulation of protein synthesis in mammary glands of lactating dairy cows by starch and amino acids. J. Dairy Sci. 93:3114-3127.

Rosen, J. M., S. L. Wyszomierski, and D. Hadsell. 1999. Regulation of milk protein gene expression. Annu. Rev. Nutr. 19:407-436.

Rulquin, H., S. Rigout, S. Lemosquet, and A. Bach. 2004. Infusion of glucose directs circulating amino acids to the mammary gland in well-fed dairy cows. J. Dairy Sci. 87:340-349.

Rutkowski, D. T., S. M. Arnold, C. N. Miller, J. Wu, J. Li, K. M. Gunnison, K. Mori, A. A. S. Akha, D. Raden, and R. J. Kaufman. 2006. Adaptation to ER stress is mediated by differential stabilities of pro-survival and pro-apoptotic mRNAs and proteins. PLoS Biol. 4:e374.

Rutkowski, D. T., and R. S. Hegde. 2010. Regulation of basal cellular physiology by the homeostatic unfolded protein response. J. Cell Biol. 189:783-794.

Sano, R., and J. C. Reed. 2013. ER stress-induced cell death mechanisms. Biochim. Biophys. Acta 1833:3460-3470.

Sauvant, D., and P. Nozière. 2016. Quantification of the main digestive processes in ruminants: The equations involved in the renewed energy and protein feed evaluation systems. Animal 10:755-770.

Scholzen, T., and J. Gerdes. 2000. The Ki-67 protein: From the known and the unknown. J. Cell. Physiol. 182:311-322. 
Schwab, C. G., L. D. Satter, and A. B. Clay. 1976. Response of lactating dairy cows to abomasal infusion of amino acids. J. Dairy Sci. 59:1254-1270.

Sciascia, Q., D. Pacheco, and S. A. McCoard. 2013. Increased milk protein synthesis in response to exogenous growth hormone is associated with changes in mechanistic (mammalian) target of rapamycin (mTOR)C1-dependent and independent cell signaling. J. Dairy Sci. 96:2327-2338.

Sciascia, Q., D. Pacheco, and S. A. McCoard. 2015. Administration of exogenous growth hormone is associated with changes in plasma and intracellular mammary amino acid profiles and abundance of the mammary gland amino acid transporter SLC3A2 in midlactation dairy cows. PLoS One 10:e0134323.

Shennan, D. B., and C. A. R. Boyd. 2014. The functional and molecular entities underlying amino acid and peptide transport by the mammary gland under different physiological and pathological conditions. J. Mammary Gland Biol. Neoplasia 19:19-33.

Sikalidis, A. K., and M. H. Stipanuk. 2010. Growing rats respond to a sulfur amino acid-deficient diet by phosphorylation of the $\alpha$ subunit of eukaryotic initiation factor 2 heterotrimeric complex and induction of adaptive components of the integrated stress response. J. Nutr. 140:1080-1085.

Tang, P. S., M. Mura, R. Seth, and M. Liu. 2008. Acute lung injury and cell death: How many ways can cells die? Am. J. Physiol. Lung Cell Mol. Physiol. 294:L632-L641.

Toerien, C. A., D. R. Trout, and J. P. Cant. 2010. Nutritional stimulation of milk protein yield of cows is associated with changes in phosphorylation of mammary eukaryotic initiation factor 2 and ribosomal S6 kinase 1. J. Nutr. 140:285-292.

Tuckow, A. P., A. A. Kazi, S. R. Kimball, and L. S. Jefferson. 2013. Identification of ubiquitin-modified lysine residues and novel phosphorylation sites on eukaryotic initiation factor $2 \mathrm{~B}$ epsilon. Biochem. Biophys. Res. Commun. 436:41-46.

Weekes, T. L., P. H. Luimes, and J. P. Cant. 2006. Responses to amino acid imbalances and deficiencies in lactating dairy cows. J. Dairy Sci. 89:2177-2187.

Wright, T. C., J. P. Cant, and B. W. McBride. 2008. Use of metabolic control analysis in lactation biology. J. Agric. Sci. 146:267-273.

Wullschleger, S., R. Loewith, and M. N. Hall. 2006. TOR signalling in growth and metabolism. Cell 124:471-484. 